\title{
PENGARUH KEPERCAYAAN DIRI DAN KECERDASAN EMOSIONAL TERHADAP HASIL BELAJAR MAHASISWA UNIVERSITAS BALIKPAPAN
}

\author{
Prita Indriawati \\ Pendidikan Ekonomi FKIP Universitas Balikpapan \\ prita@uniba-bpn.ac.id
}

\begin{abstract}
This research aims to: 1) to know the influence of self-confidence to the result of student learning of FKIP University of Balikpapan, (2) to know the influence of emotional intelligence on student learning result of FKIP University of Balikpapan, and (3) to know the influence of self confidence and emotional intelligence to student learning result FKIP University of Balikpapan. The population in this study is all students of University of Balikpapan. Sampling method with simple random sampling method as much as 30 percent of the population of students FKIP University of Balikpapan. To answer the hypothesis in this study using multiple regression with $F$ test and $t$ test. It can be concluded that: (1) there is influence of selfconfidence to result of student study of FKIP University of Balikpapan; (2) there is influence of emotional intelligence on student learning result of FKIP University of Balikpapan; and (3) there is influence of self confidence and emotional intelligence to result of student learning FKIP Universitas Balikpapan.
\end{abstract}

Keyword : Self Confidence, Emotional Intelligence

\begin{abstract}
Abstrak
Penelitian ini bertujuan untuk: 1) mengetahui pengaruh kepercayaan diri terhadap hasil belajar mahasiswa FKIP Universitas Balikpapan, (2) mengetahui pengaruh kecerdasan emosional terhadap hasil belajar mahasiswa FKIP Universitas Balikpapan, dan (3) mengetahui pengaruh kepercayaan diri dan kecerdasan emosional terhadap hasil belajar mahasiswa FKIP Universitas Balikpapan. Populasi dalam penelitian ini adalah seluruh mahasiswa Universitas Balikpapan. Cara pengambilan sampel dengan metode simple random sampling sebanyak 30 persen dari populasi yaitu mahasiswa FKIP Universitas Balikpapan. Untuk menjawab hipotesa dalam penelitian ini menggunakan regresi berganda dengan uji $F$ dan uji t. Dapat disimpulkan bahwa: (1) terdapat pengaruh kepercayaan diri terhadap hasil belajar mahasiswa FKIP Universitas Balikpapan; (2) terdapat pengaruh kecerdasan emosi terhadap hasil belajar mahasiswa FKIP Universitas Balikpapan; dan (3) terdapat pengaruh kepercayaan diri dan kecerdasan emosi terhadap hasil belajar mahasiswa FKIP Universitas Balikpapan.
\end{abstract}

Kata kunci: Kepercayaan Diri, Kecerdasan Emosional

\section{PENDAHULUAN}

Sebagai pengajar atau pendidik, guru merupakan salah satu faktor penentu keberhasilan setiap upaya pendidikan. Oleh sebab itu, seorang guru dituntut untuk dapat mengetahui dan memahami prinsip belajar serta dapat menguasai berbagai keterampilan mengajar agar proses pembelajaran dapat berlangsung dengan baik. Kemudian kepercayaan diri peserta didik terhadap hasil belajarnya merupakan salah satu faktor yang mempengaruhi hasil belajar siswa dalam proses pembelajaran, hal ini terkait dengan adanya pandangan peserta didik terhadap pendidik dalam mengajar di kelas. Sedangkan kecerdasan emosional merupakan salah satu faktor yang ada dalam diri peserta didik terhadap hasil belajarnya. 
Seorang peserta didik mampu menguasai atau megerjakan hasil berlajar, berarti peserta didik tersebut mempunyai kepercayaan diri dan kecerdasan emosioanal yang baik terhadap hasil belajarnya, sehingga peserta didik tersebut tidak melakukan usaha untuk menyontek. Sedangkan seorang peserta didik tidak mampu menguasai hasil belajarnya berarti peserta didik tersebut tidak mempunyai kepercayaan diri terhadap hasil belajarnya, dan kecerdasan emosionalnya semakin berkurang.

Menurut Alhadza (2004) kata menyontek sama dengan cheating. Beliau mengutip pendapat bower mendefinisikan cheating adalah perbuatan yang menggunakan cara-cara yang tidak sah untuk tujuan yang sah/terhormat yaitu mendapatkan keberhasilan akademis atau menghindari kegagalan akademis. Salah satu faktor yang mempengaruhi perilaku kepercayaan diri dan kecerdasan emosional.

Menurut Litnoff (2010) Percaya diri adalah sifat yang diinginkan oleh banyak orang tetapi mungkin sulit untuk mengukurnya, terutama dalam diri orang lain. Orang yang percaya diri yakin bahwa diri dan dapat menggapai sukses. Seseorang yakin bahwa didalam dirinya memiliki kemampuan untuk mengatasi apa pun yang muncul dan mempunyai keyakinan yang tidak patah semangat jika gagal.

Kepercayaan diri suatu bagian dari kehidupan yang unik dan berharga karena dengan kepercayaan diri seseorang akan lebih berani dalam menyampaikan pendapat didepan orang banyak dan lebih percaya dengan kemampuan yang dimilikinya. Tapi pada kenyataannya masih banyak yang belum bisa menerapkan percaya diri terlihat ketika kesulitan dalam mengkomunikasikan pendapat kepada orang lain, dan menghindari berbicara didepan umum karena takut orang lain akan menyalahkannya. Tetapi berbeda dengan mahasiswa FKIP Universitas Balikpapan kepercayaan dirinya lebih tinggi karena dia merasa lebih mengetahui belajar sampai tingkat perguruan tinggi, merasa lebih memiliki pendidikan sampai perguruan tinggi dan karena merasa dirinya menjadi kakak kelas.

Tanda-tanda seseorang yang kurang percaya diri pada diri sendiri dalam supriyo (2008) antara lain sebagai berikut: (1) Perasaan takut atau gemetar disaat berbicara dihadapan orang banyak. (2) Sikap pasrah pada kegagalan, memandang masa depan suram. (3) Perasaan kurang dicintai/kurang dihargai oleh lingkungan sekitarnya, (4) Selalu berusaha menghindari tugas, tanggung jawab dan pengorbanan, (5) Kurang senang dengan keberhasilan orang lain, terutama rekan sebaya/seangkatan, (6) Sensitivitas batin yang berlebihan, mudah tersinggung, cepat marah dan pendendam, (7) Suka menyendiri dan cenderung bersikap egosentris, (8) Terlalu berhati-hati ketika kehadapan dengan orang lain sehingga perilakunya terlihat kaku, (9) Pergerakan agak terbatas, seolah-olah sadar jika dirinya memang mempunyai banyak kekurangan, (10) Sering menolak jika diajak ke tempat yang ramai.

Menurut Litvinoff (2010) ada sepuluh langkah dalam membangun rasa percaya diri sebagi berikut: (1) mengambil tindakan, (2) meningkatkan energy, (3) membangun cadangan rasa percaya diri, (4) jujur terhadap diri sendiri, (5) mengatasi rasa takut, (6) menciptakan hubungan yang baik, (7) bertindak sampai menjadi nyata, (8) memperbaiki keadaan sekarang, (9) melupakan masa lalu, (10) mengubah pikiran.

Selain kepercayaan diri kecerdasan emosional juga mempengaruhi perilaku menyontek. Kecerdasan emosionla adalah adalah kemampuan seseorang untuk mengatur kehidupan emosinya dengan cara 
menjaga keselarasan emosi dan pengucapannya melalui keterampilan kesadaran diri, pengendalian diri, motivasi diri, empati dan keterampilan sosial.

Menurut Goleman (2000), kecerdasan emosional adalah kemampuan seseorang mengatur kehidupan emosinya dengan inteligensi (to manage our emotional life with intelligence); menjaga keselarasan emosi pengumkapannya (the appropriateness of emotion and its expression) melalui keterampilan kesadaran diri, pengendalian diri, motivasi diri, empati dan keterampilan social.

Aspek kecerdasan emosional menurut (Goleman 2000) sebagai berikut: (1) mengenali emosi diri merupakan suatu kemampuan untuk mengenali perasaan sewaktu perasaan itu terjadi, (2) mengelola emosi merupakan kemampuan individu dalam menangani perasaan agar dapat terungkap dengan tepat atau selaras, sehingga tercapai keseimbangan dalam diri individu, (3) emotivasi diri sendiri berarti memiliki ketekunan untuk menahan diri terhadap kepuasan dan mengendalikan dorongan hati, serta mempunyai perasaan motivasi yang positif, yaitu antusianisme, gairah, optimis dan keyakinan diri, (4) mengenali emosi orang lain yang disebut empati, (5) membina hubungan merupakan suatu keterampilan yang menunjang popularitas, kepemimpinan dan keberhasilan antar pribadi.

Menurut Anthony (2014) tujuh prinsip utama dalam kecerdasan emosional yaitu: (1) bukan emosi yang mengendalikan saya, tapi sayalah yang mengendalikan saya, (2) sayalah pencipta suasana dan isi interaksi saya dengan orang lain, (3) pikiran memenuhi emosi saya, selanjutnya emosi memengaruhi kualitas tindakan saya, (4) dibalik sikap dan perilaku seseorang, terdapat emosi terselubung, (5) pertarungan emosi menyenangkan dan tidak menyenangkan, menyebabkan sukses atau gagalnya seseorang, (6) suatu kebiasaan lama dapat diubah, jika terdapat kebiasaan baru yang lebih menyenangkan dari kebiasaan sebelumnya, (6) emosi adalah kekuatan dahsyat yang dapat melampaui batas kesadaran dan fisik manusia.

Menurut Jack Block dalam Goleman (2002) dari hasil penelitiannya menyebutkan bahwa ciri-ciri seseorang memiliki kecerdasan emosi: (1) Kaum pria yang tinggi kecerdasan emosinya, secara sosial mantap, mudah bergaul dan jenaka, tidak mudah takut atau gelisah. Seseorang yang berkemampuan besar untuk melibatkan diri dengan orang-orang atau permasalahan, untuk memikul tanggung jawab, mudah simpatik dan mempunyai pandangan moral. Orang tersebut akan merasa nyaman dengan dirinya sendiri, dengan orang lain dan dunia pergaulan lingkungannya. (2) Kaum wanita yang cerdas emosinya cenderung bersikap tegas dan mengungkapkan perasaannya secara langsung, memandang dirinya sendiri secara positif, kehidupan memberi makna baginya. Sebagaimana dengan kaum pria, kemampuan seorang pria yang mudah bergaul dan ramah serta mengungkapkan perasaannya dengan takaran yang wajar, orang tersebut mampu menyesuaikan diri dengan beban stress. Kemantapan pergaulannya membuat seseorang mudah menerima orang-orang baru, orang tersebut cukup nyaman dengan dirinya sendiri sehingga selalu ceria, spontan, dan terbuka.

Penelitian yang relevan dijadikan rujukan adalah : (1) Mufarohah (2013) yang menunjukkan terdapat hubungan positif ( $r_{x y}$ 0,288 ; dengan sig > 0,05) yang artinya hubungan antara variabel Percaya Diri dan Intensitas Perilaku Menyontek adalah negatif tidak signifikan dengan mendapatkan nilai 0,26 dan nilai signifikansinya Sig 0,83 dan (2) dilihat dari hasil analisis data Jurnal Talenta Psikologi: Vol. 1, No. 2 Agustus 2012 oleh Anniez 
Rahmawati Musslifah menunjukan bahwa nilai $F$ sebesar 2,813 dengan $p=0,094$ ( $p$ > $0,05)$ hasil tersebut menunjukan bahwa terdapat pengaruh negatif yang sangat signifikan antara kecerdasan emosional dengan perilaku menyontek

Berdasarkan observasi di lapangan dari pendidik menyampaikan bahwa ratarata mahasiswa Universitas Balikpapan dalam mengerjakan Ujian Semester melakukan perilaku menyontek, hal ini disebabkan karena peserta didik kurang percaya diri dalam mengerjakan soal. Dari sisi kecerdasan emosionalnya peserta didik juga miliki nilai moral dan spiritual yang kurang sehingga tanpa merasa canggung peserta didik mampu melakukan perbuatan tersebut. Berdasarkan hal tersebut peneliti ingin meneliti tentang analisis kepercayaan diri dan kecerdasan emosional terhadap hasil belajar mahasiswa FKIP Universitas Balikpapan.

\section{METODE PENELITIAN}

Jenis penelitian ini adalah penelitian kuantitatif. Teknik pengambilan sampel pada umumnya dilakukan secara random, pengumpulan data menggunakan instrumen penelitian, analisis data bersifat kuantitatif/statistik dengan tujuan untuk menguji hipotesis yang telah ditetapkan. (Sugiono 2014).

$$
\text { Sugiyono (2014) yang dimaksud }
$$
dengan populasi adalah wilayah generalisasi yang terdiri atas: obyek/subyek yang mempunyai kualitas dan karakteristik tertentu yang ditetapkan oleh peneliti untuk dipelajari dan kemudian ditarik kesimpulanya. Dalam penelitian ini yang menjadi populasi adalah seluruh mahasiswa FKIP Universitas Balikpapan.

Menurut Sugiyono (2014) sampel adalah bagian dari jumlah dan karakteristik yang dimiliki oleh populasi tersebut. Darmawan (2013) mengatakan bahwa jika ukuran populasinya di atas 1000 sampel sekitar 10\% sudah cukup, tetapi jika ukuran populasinya sekitar 100 sampelnya paling sedikit 30\%. Peneliti mengambil sampel sebanyak 30\% dari jumlah mahasiswa FKIP Universitas Balikpapan. Untuk mendapatkan sampel peneliti menggunakan teknik simple random sampling.

Penelitian ini menggunakan dua variabel bebas yaitu Kepercayaan Diri $\left(X_{1}\right)$ dan Kecerdasan emosional $\left(X_{2}\right)$. Sedangkan yang dijadikan sebagai variabel terikat adalah hasil belajar $(Y)$.

Pengukuran tingkat hubungan atau pengaruh $X_{1}$ terhadap $Y$ (Kepercayaan Diri terhadap Hasil Belajar) dan $X_{2}$ terhadap $Y$ (Kecerdasan Emosional terhadap Hasil Belajar) dianalisis dengan regresi sederhana. Sedangkan hubungan atau pengaruh $X_{1}$ dan $X_{2}$ secara simultan terhadap $Y$ (Kepercayaan Diri dan Kecerdasan Emosional terhadap hasil belajar) dianalisis dengan regresi ganda.

Semua perhitungan dalam analisis ini, baik untuk pengujian persyaratan analisis maupun pengujian untuk pembuktian hipotesis dilakukan dengan bantuan program Komputer berbantuan Microsoft Excel.

Tabel 1 Kisi-kisi instrumen penelitian

\begin{tabular}{|c|c|c|c|c|}
\hline \multirow{2}{*}{ No } & \multirow{2}{*}{ Variabel } & \multirow{2}{*}{ Indikator } & \multicolumn{2}{|c|}{ Butir Pernyataan } \\
\hline & & & Positif & Negatif \\
\hline \multirow{3}{*}{1.} & \multirow{3}{*}{$\begin{array}{l}\text { Kepercayaan } \\
\text { Diri }\end{array}$} & 1.Tampil Percaya Diri & $1,2,3,25$ & $4,5,6,27$ \\
\hline & & 2.Bertindak Independen & $7,8,9,29$ & $\begin{array}{l}10,11,12, \\
32\end{array}$ \\
\hline & & 3.Menyatakan keyakinan atas kemampuan & $13,14,15,30$ & $16,17,18,31$ \\
\hline
\end{tabular}




\begin{tabular}{|c|c|c|c|c|}
\hline & & \multicolumn{3}{|l|}{ sendiri } \\
\hline & & 4. Memilih tantangan atau konflik & $19,20,21,26$ & $22,23,24,28$ \\
\hline \multirow{5}{*}{2.} & \multirow{5}{*}{$\begin{array}{l}\text { Kecerdasan } \\
\text { Emosional }\end{array}$} & 1. Sadar diri & $1,2,21$ & $3,4,22$ \\
\hline & & 2. Bisa Berempati & $5,6,23$ & $7,8,24$ \\
\hline & & 3. Bermotivasi tinggi & $9,10,25$ & $11,12,26$ \\
\hline & & 4. Berani bercita-cita & $13,14,27$ & $15,16,28$ \\
\hline & & $\begin{array}{l}\text { 5.Mampu bergaul dan membangun sebuah } \\
\text { persahabatan }\end{array}$ & 17,18 & 19,20 \\
\hline
\end{tabular}

yang menunjukkan item pernyataan reliabel sehingga dapat digunakan sebagai alat ukur

Uji instrumen pada kuesioner di atas diantaranya adalah validitas dan reliabilitas. Pengujian validitas menggunakan korelasi product moment dari Pearson, jika $r_{\text {hitung }} \geq$ 0,30 maka koefisien korelasi valid dan taraf signifikan $\alpha=5 \%$.

Berdasarkan perhitungan uji validitas untuk kuisioner kepercayaan diri terdapat 25 item yang dikatakan valid yaitu 1, 3, 4, $5,6,7,8,9,10,11,14,15,16,17,20,22$, $23,24,25,26,27,28,30,31,32$. Sedangkan item pernyataan yang tidak valid karena nilai koefisien korelasi $\leq 0,30$ sebanyak 7 item pernyataan yaitu nomor 2 , $12,13,18,19,21,29$. Sedangkan untuk kuisioner kecerdasan emosional dari 28 item pernyataan tersebut diperoleh 20 item pernyataan yang valid yaitu nomor 1, 3, 4, $5,6,7,8,9,10,12,13,14,17,18,19,20$, $21,23,26,28$. dan item pernyataan yang tidak valid karena nilai koefisien korelasi $\leq$ 0,30 sebanyak 8 item pernyataan yaitu nomor 2, 11, 15, 16, 22, 24, 25, 27

Sedangkan pengujian reliabilitas menggunakan rumus Alpha Cronbach. Nilai koefisien reliabilitas untuk kuisioner kepercayaan diri yang diperoleh sebesar $0,8462 \geq 0,70$ yang menunjukkan item pernyataan reliabel sehingga dapat digunakan sebagai alat ukur penelitian dengan kategori sangat tinggi atau sempurna. Sedangkan nilai koefisien reliabilitas untuk kuisioner kecerdasan emosional diperoleh sebesar $0,8196 \geq 0,70$ penelitian dengan kategori sangat tinggi atau sempurna.

Teknik pengumpulan data adalah cara yang dilakukan oleh peneliti untuk memperoleh data yang benar sesuai objek yang diteliti dan selanjutnya akan dianalisis sesuai dengan kebutuhan dan ditarik kesimpulan. Teknik pengumpulan data pada penelitian ini adalah dokumentasi, kuesioner, dan tes hasil belajar.

Pada penelitian ini ada beberapa uji prasyarat analisis yang harus dipenuhi, yaitu: uji normalitas, linearitas, dan multikolinearitas. Sedangkan uji hipotesis dilakukan setelah uji prasyarat. Pengujian hipotesis menggunakan analisis regresi berganda. Analisis regresi berganda digunakan oleh peneliti, bila peneliti bermaksud meramalkan bagaimana keadaan variabel dependent (Sugiyono, 2016). Selanjutnya peneliti melanjutkan dengan uji lanjut yaitu uji dengan menggunakan uji-t dan uji-F.

\section{PEMBAHASAN}

Untuk pengujian normalitas masing-masing data peneliti menggunakan uji Liliefors. Pengujian ini dilakukan dengan uji Liliefors padataraf signifikan $\alpha=$ 0,05 dengan kriteria pengujian berdistribusi normal apabila $L_{\text {hitung }}<L_{\alpha, n}$. Ringkasan hasil perhitungan uji normalitas mengenai kepercayaan diri $\left(X_{1}\right)$, kecerdasan emosional $\left(X_{2}\right)$, dan hasil belajar mahasiswa $(Y)$ dapat dilihat pada tabel di bawah ini: 
Tabel 2 Ringkasan Hasil Uji Normalitas

\begin{tabular}{cccccc}
\hline Variabel & $\boldsymbol{N}$ & $\boldsymbol{A}$ & $\boldsymbol{L}_{\text {hitung }}$ & $\boldsymbol{L}_{\mathbf{0 , 0 5} \mathbf{1 0 8}}$ & Keputusan Uji \\
\hline$X_{1}$ & 108 & 0,05 & 0,0689 & 0,0853 & $H_{0}$ diterima \\
\hline$X_{2}$ & 108 & 0,05 & 0,0636 & 0,0853 & $H_{0}$ diterima \\
\hline$Y$ & 108 & 0,05 & 0,0804 & 0,0853 & $H_{0}$ diterima \\
\hline $\begin{array}{c}\text { Pengujian } \\
\text { mengetahui }\end{array}$ & $\begin{array}{l}\text { linearitas digunakan } \\
\text { apakah }\end{array}$ & setiap variabel & variabel terikat. & Uji linearitas \\
penelitian menggunakan diagram pencar.
\end{tabular}

untuk mengetahui apakah setiap variabel penelitian menggunakan diagram pencar.

bebas memiliki hubungan linear terhadap

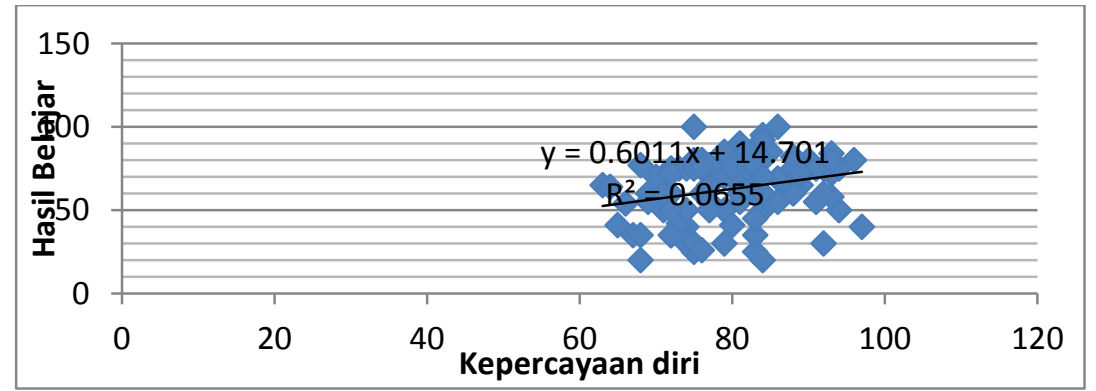

Gambar 1. Diagram Pencar $X_{1}$ dan $Y$

Pada gambar 4.1 terbentuk satu garis lurus yang condong miring ke kanan dan banyak titik-titik yang tersebar diantara garis. Sehingga dapat disimpulkan bahwa hubungan antara kepercayaan diri $\left(X_{1}\right)$ dan hasil belajar mahasiswa $(Y)$ adalah cenderung linear positif.

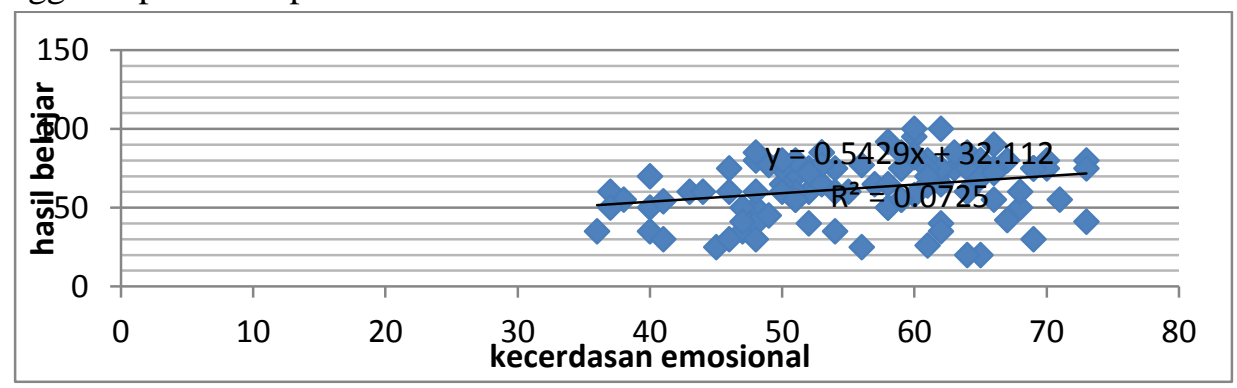

Gambar 2. Diagram Pencar $X_{2}$ dan $Y$

Pada gambar 4.2 terbentuk satu garis lurus yang condong miring ke kanan dan banyak titik-titik yang tersebar diantara garis. Sehingga dapat disimpulkan bahwa hubungan antara kecerdasan emosional $\left(X_{2}\right)$ dan hasil belajar mahasiswa $(Y)$ adalah cenderung linear positif.

Pengujian multikolinearitas digunakan untuk mengetahui ada atau tidak ada hubungan antara variabel bebas. Pengujian ini dilakukan dengan kriteria tidak terjadi hubungan kepercayaan diri dan kecerdasan emosional apabila Tol $\leq 0,1$ atau nilai VIF $\geq 10$. Ringkasan hasil perhitungan uji multikolinearitas variabel kepercayaan diri $\left(X_{1}\right)$ dan kecerdasan emosional $\left(X_{2}\right)$ dapat dilihat pada tabel di bawah ini:

Tabel 3. Ringkasan Hasil Uji Multikolinearitas

\begin{tabular}{ccccc}
\hline Hubungan antara & $\boldsymbol{r}_{\boldsymbol{1 2}}$ & $\boldsymbol{T o l}$ & $\boldsymbol{V I F}$ & Keputusan Uji \\
\hline$X_{1}$ dan $X_{2}$ & 0,4919 & 0,7580 & 1,3193 & $H_{0}$ ditolak \\
\cline { 1 - 2 } Berdasarkan tabel tersebut terlihat & bahwa tidak terjadi hubungan & antara \\
a hubungan antara $X_{1}$ dan $X_{2}$ diperoleh & \multicolumn{2}{c}{ variabel $X_{1}$ dan $X_{2}}$. \\
Tol $=0,7580 \geq 0,1$ dan nilai VIF $=$ & \multicolumn{3}{c}{ Setelah dilakukan perhitungan } \\
$3 \leq$ 10. Sehingga dapat disimpulkan & analisis regresi berganda, diperoleh
\end{tabular}


persamaan regresi $\widehat{Y}=-3,1892+$ $0,4842 X_{1}+0,4816 X_{2}$. Dari persamaan tersebut terlihat bahwauntuk koefisien regresi $X_{1}$ dan $X_{2}$ bernilai positif sehingga pengaruhnya bersifat positif yang artinya semakin tinggi kepercayaan diri dan kecerdasan emosi maka semakin tinggi pula hasil belajar mahasiswa. Sebaliknya apabila semakin rendah kepercayaan diri dan kecerdasan emosi maka semakin rendah pula hasil belajar mahasiswa. Dan jika hasil belajar mahasiswa nilainya kurang memuaskan belum tentu kepercayaan diri dan kecerdasan emosi buruk.

Andaikan mahasiswa tidak mempunyai kepercayaan diri dengan $X_{1}=0$ dan mahasiswa tidak memiliki kecerdasan emosi dengan $X_{2}=0$, maka hasil belajar mahasiswa yang diperoleh bernilai negatif yaitu -3,1892. Akan tetapi apabila kepercayaan diri tinggi (misal skor $X_{1}=97$ ) dengan mahasiswa memiliki kecerdasan emosi dengan skor $\left(X_{2}=73\right)$ maka didapatkan hasil belajarnya yaitu 78,935. Berarti hasil belajar mahasiswa meningkat (bernilai positif).

Hasil uji hipotesis pertama dalam penelitian ini menunjukkan bahwa terdapat pengaruh kepercayaan diri terhadap hasil belajar mahasiswa FKIP Universitas Balikpapan. Hal ini ditunjukkan dari hasil perhitungan dari uji $t_{\text {hitung }}=1,9572>$ $t_{0,05 ; 105}=1,6594$ dengan $\mathrm{n}=108$ pada taraf signifikan $\alpha=0,05$ yang mengakibatkan $H_{0}$ ditolak. Terdapat pengaruh kepercayaan diri tehadap hasil belajar mahasiswa FKIP Universitas Balikpapan disebabkan oleh beberapa hal diantaranya kepercayaan diri mahasiswa sudah tergolong baik. Terlihat dari hasil kuesioner pada penelitian ini yaitu atau inisiatif mahasiswa untuk belajar sangat tinggi. Selain itu ada beberapa mahasiswa malas atau bosan mempelajari kembali materi yang terlalu banyak diulang-ulang. Kemudian dalam mengerjakan tugas yang diberikan oleh dosen maupun tes hasil belajar mahasiswa mengerjakan secara mandiri dan mahasiswa selalu berdiskusi kepada temannya apabila mengalami kesulitan dalam memahami materi maupun mengerjakan soal yang diberikan oleh dosen. Sehingga kepercayaan diri mahasiswa berpengaruh secara signifikan terhadap hasil belajar mahasiswa. Dengan demikian dapat dikatakan apabila semakin tinggi kepercayaan diri mahasiswa maka semakin tinggi hasil belajarnya, sebaliknya apabila semakin rendah kepercayaan diri mahasiswa maka semakin rendah pula hasil belajar mahasiswa atau belum optimal.

Hasil uji hipotesis pertama dalam penelitian ini menunjukkan bahwa terdapat pengaruh kecerdasan emosi terhadap hasil belajar mahasiswa FKIP Universitas Balikpapan. Hal ini ditunjukkan dari hasil perhitungan dari uji $t_{\text {hitung }}=2,2674>$ $t_{0,05 ; 105}=1,6594$ dengan $\mathrm{n}=108$ pada taraf signifikan $\alpha=0,05$ yang mengakibatkan $H_{0}$ ditolak. Terdapat pengaruh kecerdasan emosi tehadap hasil mahasiswa FKIP Universitas Balikpapan yang disebabkan oleh beberapa hal diantaranya yaitu mahasiswa memiliki kecerdasan emosi yang baik pada kemampuan yang dimilikinya, serta keinginan cara mahasiswa dalam mengontrol emosinya, Ketika mahasiswa mampu bergaul dengan temannya, muncullah pertemanan yang ada pada dirinya. Sehingga mahasiswa bisa saling membantu dalam diskusi kelompok ataupun dalam penyampaian materi ketika presentasi. Kemudian mahasiswa selalu memberikan kesempatan kepada temannya untuk bertanya apabila ada temannya yang kesulitan dalam memahami materi yang telah disampaikan, sehingga dapat meningkatkan rasa ingin tahu mahasiswa terhadap suatu masalah yang dihadapinya serta dapat memotivasi mahasiswa untuk bertanya apabila ada penjelasan yang 
kurang dimengerti. Selanjutnya dalam membuka pembelajaran dosen mengarahkan kepada mahasiswa untuk memberikan motivasi kepada temannya sehingga mahasiswa menjadi semangat untuk belajar.

Hasil uji hipotesis ketiga menunjukkan bahwa terdapat pengaruh signifikan dari pengaruh kepercayaan diri dan kecerdasan emosi terhadap hasil belajar mahasiswa FKIP Universitas Balikpapan. Hal ini ditunjukkan dari hasil perhitungan dari uji $\mathrm{F}_{\text {hitung }}=6,9631>\mathrm{F}_{0,05 ; 2 ; 105}=$ 3,0829 dengan $\mathrm{n}=108$ pada taraf signifikan $\alpha=0,05$ yang mengakibatkan $\mathrm{H}_{0}$ ditolak. Selanjutnya dapat dilihat dari persamaan regresi berganda $\widehat{Y}=$ $-3,1892+0,4842 X_{1}+0,4816 X_{2}$.

Berdasarkan persamaan tersebut terlihat bahwa koefisien regresi dari masing-masing variabel independen bernilai positif. Artinya kepercayaan diri dan kecerdasan emosi secara bersama-sama memberikan kontribusi dan pengaruh positif terhadap hasil belajar.

Selanjutnya untuk rata-rata nilai tes mahasiswa tergolong baik serta mahasiswa sangat percaya diri ketika mengerjakan soal-soal, hal ini disebabkan karena proses pembelajaran di kelas dan cara mengajar dosen disukai oleh mahasiswa.

Hal ini disebabkan karena kecerdasan emosi mahasiswa sudah baik. Terlihat dari hasil kuesioner dalam penelitian ini, cara mahasiswa dalam bergaul dan berdiskusi kelompok, serta cara mahasiswa dalam menyampaikan materi atau mempresentasikan pembelajaran dengan jelas kepada temannya. Apabila ada mahasiswa mengalami kesalahan dalam mempresentasikan, teman satu kelompoknya membantu untuk memperbaiki. Kemudian mahasiswa selalu memberikan kesempatan kepada kelompok lain untuk bertanya apabila mengalami kesulitan dalam memahami materi yang telah disampaikan, sehingga dapat meningkatkan rasa ingin tahu mahasiswa terhadap suatu masalah yang dihadapinya serta meningkatkan kecerdasan emosi. Selain itu mahasiswa sering mengikuti kegiatan seminar atau workshop menambah wawasan, pengetahuan dan keterampilan mengajar yang dimiliki dapat diterapkan saat pembelajaran di kelas.

Berdasarkan hasil penelitian tersebut peneliti menyimpulkan bahwa semakin tinggi kepercayaan diri dan kecerdasan emosi maka semakin tinggi hasil belajar mahasiswa. Sebaliknya apabila semakin rendah kepercayaan diri dan kecerdasan emosi rendah pula hasil belajar mahasiswa rendah.

Hasil penelitian ini relevan dengan penelitian Faya Sukma Putri (2012) yaitu ada pengaruh positif kecerdasan emosional dan kepercayaan diri terhadap prestasi belajar mata pelajaran akuntansi pada siswa kelas XI IS SMA Negeri 3 Magelang baik secara simultan maupun parsial.

\section{SIMPULAN}

Berdasarkan hasil pengujian hipotesis dan pembahasan dari penelitian, peneliti mendapatkan beberapa kesimpulan antara lain: (1) terdapat pengaruh kepercayaan diri terhadap hasil belajar mahasiswa FKIP Universitas Balikpapan; (2) terdapat pengaruh kecerdasan emosi terhadap hasil belajar mahasiswa FKIP Universitas Balikpapan; dan (3) terdapat pengaruh kepercayaan diri dan kecerdasan emosi terhadap hasil belajar mahasiswa FKIP Universitas Balikpapan.

\section{DAFTAR RUJUKAN}

Anniez R. M. (2012). Perilaku Menyontek Siswa Ditinjau dari Kecenderungan 
Locus Of Control. Jurnal Talenta Psikologi: Vol. 1, No. 2 Agustus 2012.

Anthony, D.M. (2014). Smart Emotion. Jakarta: Gramedia

Arikunto, S. (2013). Prosedur Penelitian Suatu Pendekatan Praktik. Jakarta: Bumi Aksara.

Asrori, M. (2012). Psikologi Pembelajaran. Bandung: Cv. Wacana Prima.

Budiyono. (2009). Statistika Untuk Penelitian. Surakarta: UNS Press.

Budiyono. (2013). Metodologi Penelitian Pendidikan. Surakarta: UNS Press.

Daniel, G. (2002) Kiat-kiat Membesarkan anak yang Memiliki Kecerdasan Emosional. Jakarta: Gramedia.

Darmawan, D. (2013). Metode Penelitian Kuantitatif. Bandung: PT Remaja Rosdakarya.

Iyan, A.R. (2014). Buku Pintar Tampil Percaya Diri. Yogyakarta: Araska

Jihad, A., \& Haris, A. (2013). Evaluasi Pembelajaran. Yogyakarta: Multi Pressindo.
Lawrence. (2001) Mengajarkan Emotional Intelligence. Jakarta: Gramedia.

Litvinoff, S. (2010). Sepuluh Langkah Membangun Kepercayaan Diri. Tangerang: Karisma.

Monty P. S. (2003). Mendidik Kecerdasan. Jakarta: Media Grafika.

Mufarohah. (2013). Relationship SelfConfident With Student Cheating Behavior Madrasah Aliyah Salafiyah Bangil Pasuruan class XI. Thesis. Malang: Faculty of Psyichology: State Islamic University of Malang.

Putri, F.S. 2012. Pengaruh Kecerdasan Emosional dan Kepercayaan Diri Terhadap Prestasi Belajar Mata Pelajaran Akuntansi Kelas XI IS SMA Negeri 3 Magelang. Skripsi. Semarang: Universitas Negeri Semarang.

Setyosari. (2010). Metode Penelitian Pendidikan dan Pengembangan. Jakarta: Kencana.

Sugiyono. (2014). Metode Penelitian Pendidikan Pendekatan Kuantitatif, Kualitatif, dan $R \& D$. Bandung: Alfabeta.

Sugiyono. (2016). Statistika Untuk Penelitian. Bandung: Alfabeta. 